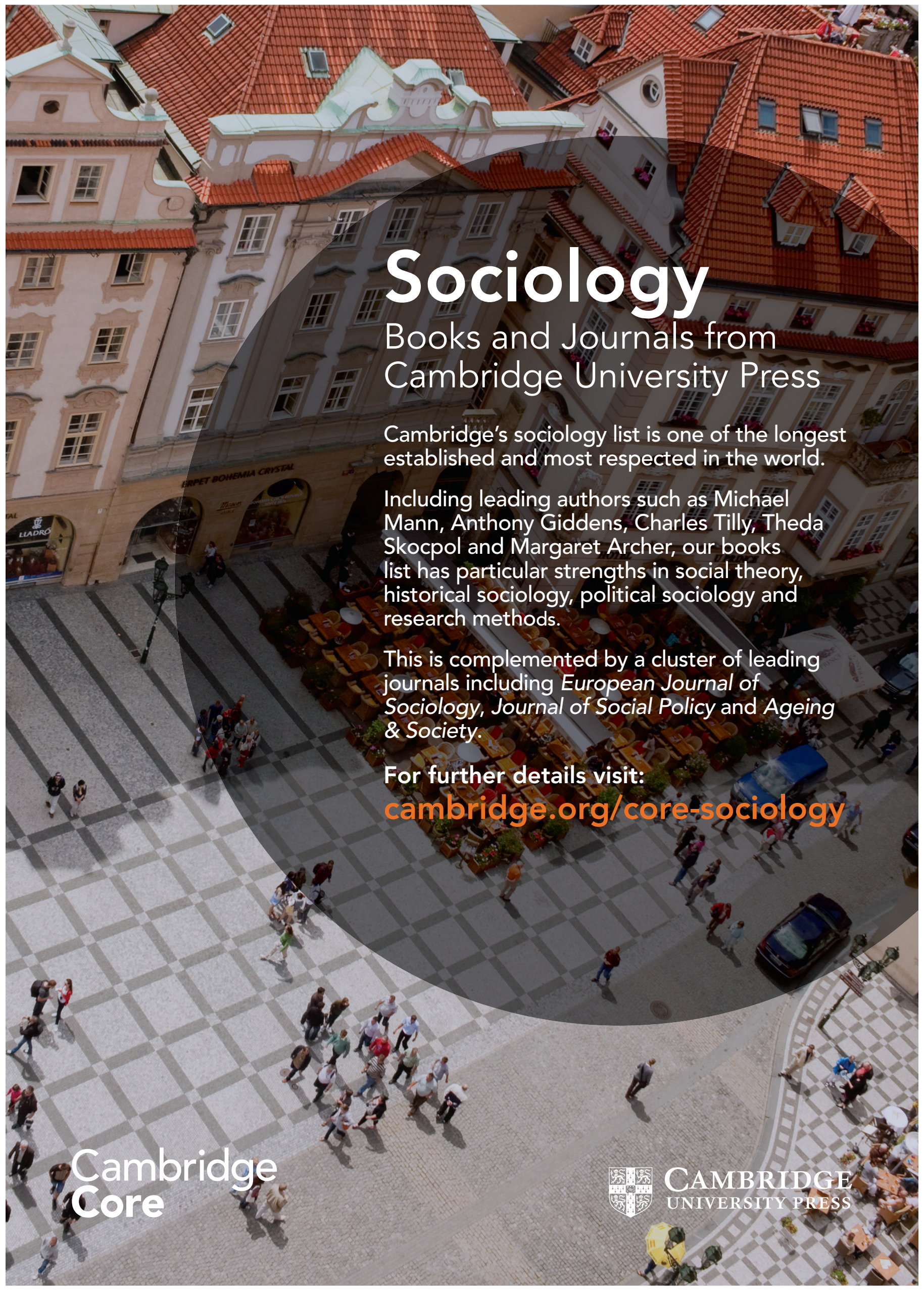




\section{Cambridge Journals Digital Archive}

Knowledge is no longer shelved

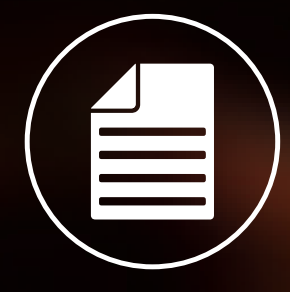

Over 900,000 articles from $300+$ journals

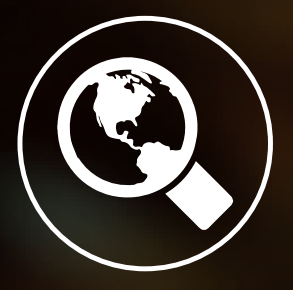

Over 245 years of world class research

Available in collections, bespoke packages and as individual journal archives

cambridge.org/core-cjda UNIVERSITY PRESS 


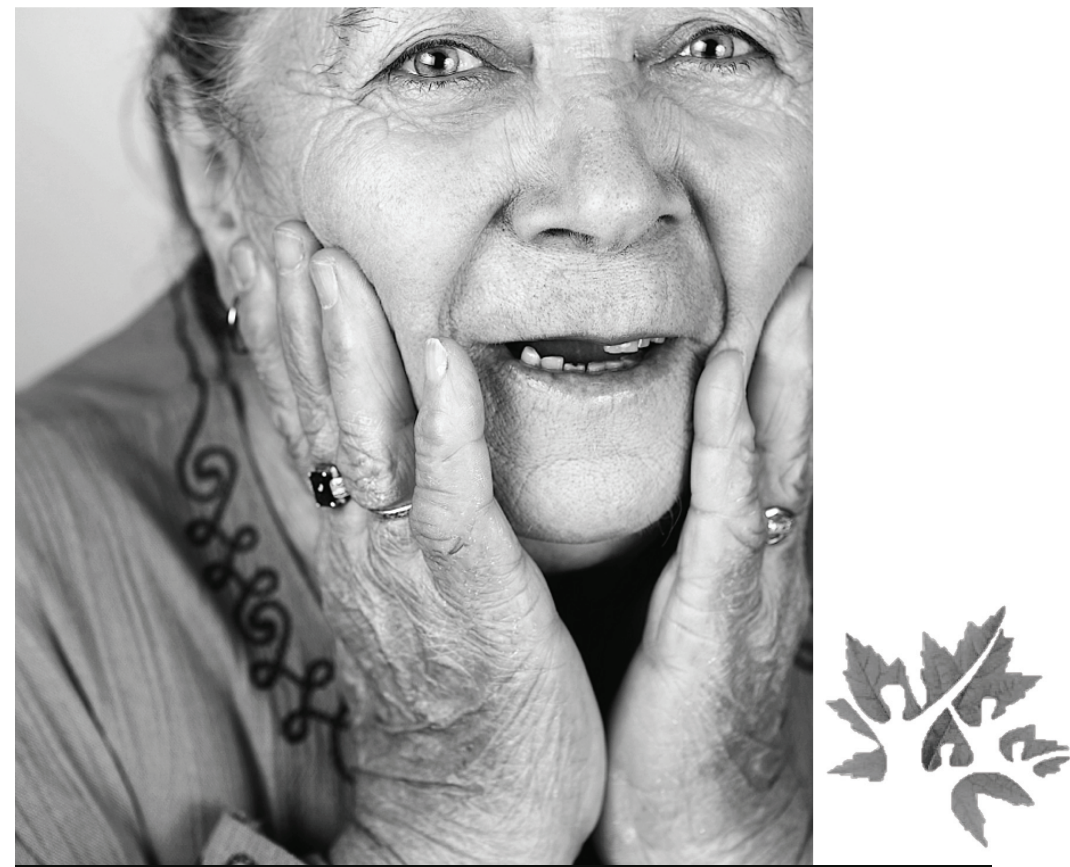

CIHR Institute of Aging

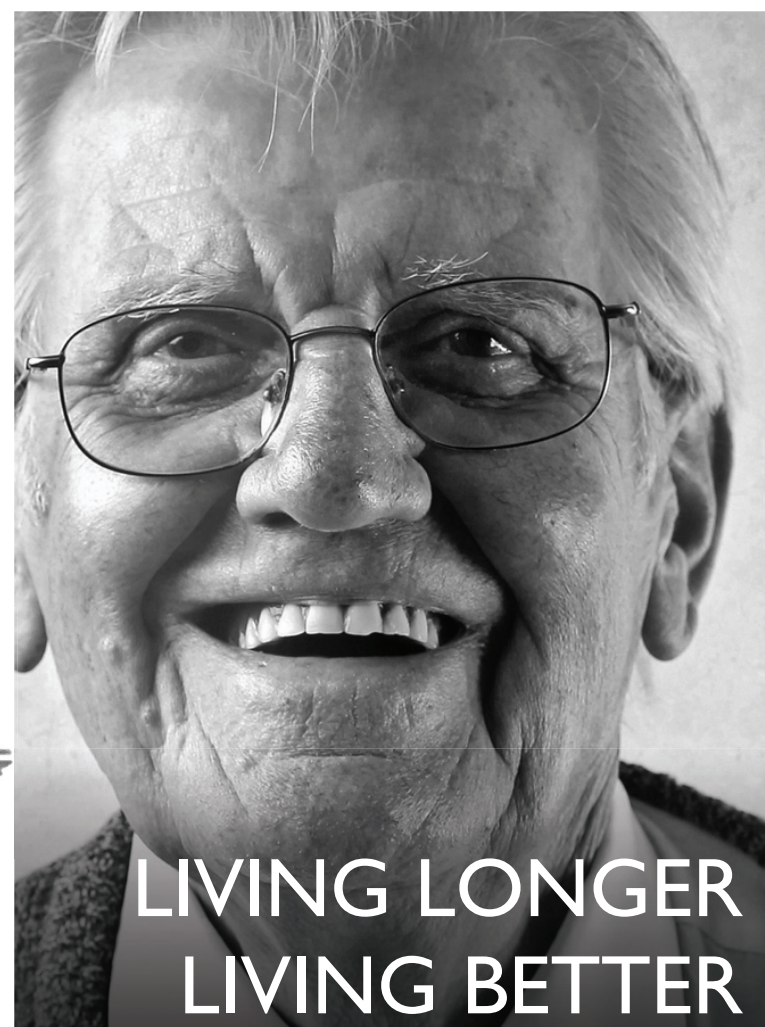

VIVRE PLUS VIVRE MIEUX Institut du vieillissement des IRSC
$(8$

To learn more about us,
please visit: www.cihr-irsc.gc.ca/e/8671
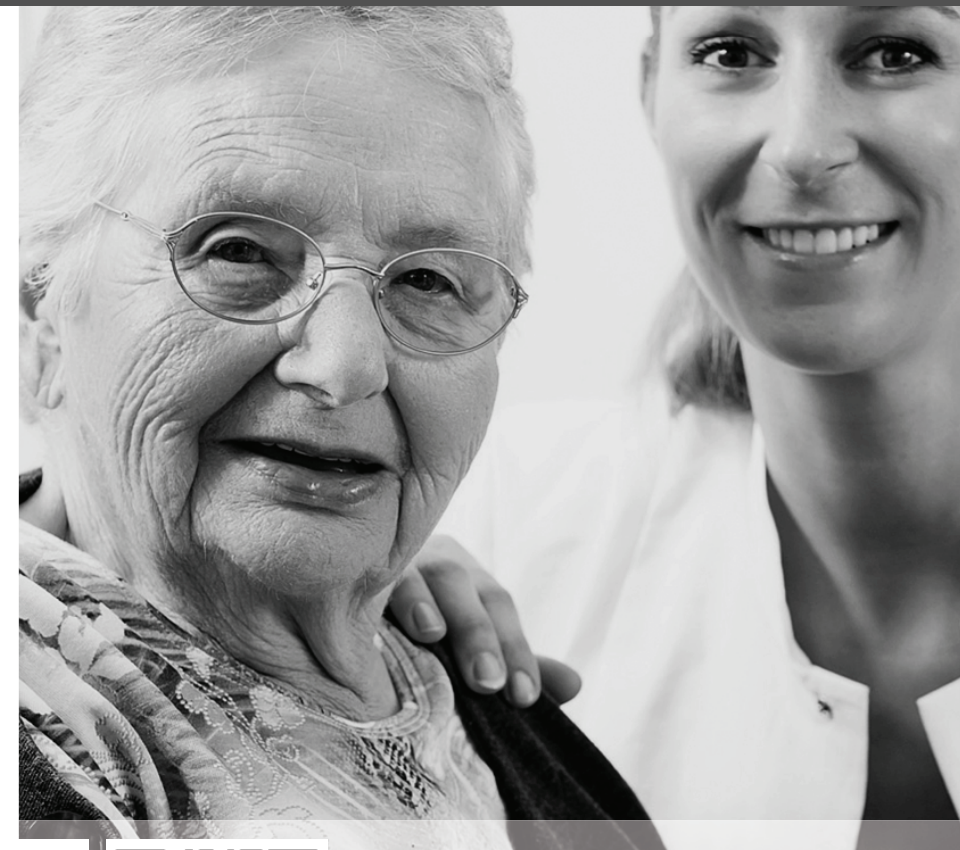

Sill

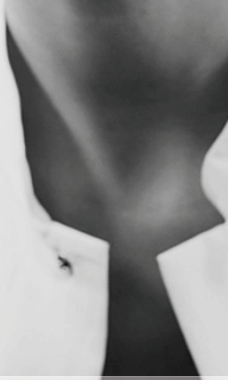

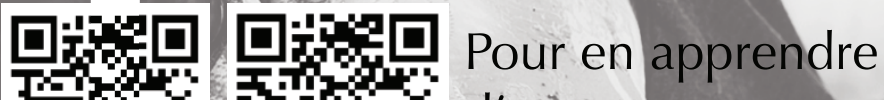
(x) d'avantage sur noưs, visitez : www.irsc-cihr.gc.ca/f/8671

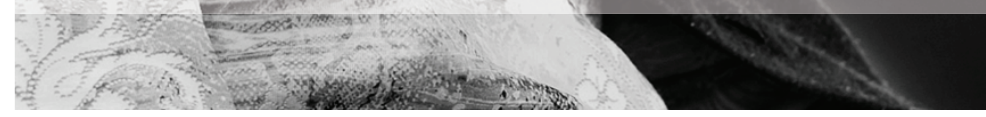

Canadlä 
CANADIAN JOURNAL ON AGING

General Information and Instructions to Authors

Canadian Journal on Aging is a refereed, quarterly publication of the Canadian Association on Gerontology. It publishes manuscripts on aging concerned with biology, health sciences, psychology, social sciences, and social policy and practice. The Journal welcomes articles reporting original research, as well as conceptual and theoretical papers which significantly advance knowledge or understanding in gerontology. Authors are asked to bear in mind the multidisciplinary nature of the readership when writing their manuscripts. In particular, care should be taken to draw out the implications of the analysis for readers in other fields and other disciplines. Journal space is also available for Book Reviews, Research Notes, and Policy and Practice Notes. A Research Note will be a brief report with theoretical or policy implications. A Policy or Practice Note will be a brief report with implications for improving practice or the delivery of a specific service. Either section can be used to present important case studies, psychometric reports, Canadian norms for standardized tests, assessment of methodological approaches findings from pilot and replication studies, and summaries of program evaluation studies. Authors should indicate clearly whether their submission is for Research Notes or Policy and Practice Notes. The maximum length for these submissions is 5,000 words plus references, figures and tables. Authors of a Note must indicate, when applicable, that a more detailed report will be provided upon request.

\section{Submission and acceptance of manuscripts}

Canadian Journal on Aging accepts manuscript submissions through the ScholarOne Manuscripts system at http:/ / mc.manuscriptcentral.com/cja-rcv. For questions concerning "General Information and Instructions to Authors," please contact the Editor Paul Stolee at cjarcv@uwaterloo.ca.

Submission of a paper to the CJA implies that it has not been published, nor is it under consideration by another journal; and if accepted by the CJA it is not to be published elsewhere (except as a conference proceeding) without permission.

\section{Manuscript preparation}

a. Preparing the manuscript. It is recommended that PC-compatible software be used; authors must supply their final version in Word. Articles should be printed double spaced. Articles should generally contain between 3,000 and 10,000 words plus references, figures, and tables. Number pages consecutively, including all pages. A condensed title for a running head, not to exceed 40 letters and spaces should be supplied, and up to six (6) key words for abstracting purposes.

b. Title page. As a separate document (not included in the Main Document file), authors must submit a title page containing name of author, highest degree awarded, name and address of institutional affiliation, e-mail, fax, and telephone numbers as well as acknowledgements.

c. Author anonymity. The manuscript file (Main Document) must be anonymous, i.e., without any author details. The title of the manuscript, keywords, and abstract should be included in the Main Document file.

d. Abstract. Each author is required to furnish an abstract of not more than 150 words.

e. Acknowledgements. These should be included on the title page and will be incorporated in a preliminary note on the first printed page of the article.

f. Notes. All notes should be entered as endnotes and should appear immediately before the References. Footnotes are not acceptable.

g. References. The articles submitted should be written in American Psychological Association (2009, Sixth Edition) style of referencing. More information regarding this may be obtained by writing to the Editorial Office.

h. Tables. Tables should be submitted as separate files, ideally in Word table format.

i. Figures. Camera ready figures should be submitted with the final version of the paper in the following size: 43 picas $/ 71 / 4$ in. wide max. 58 picas $/ 73 / 4$ in. depth. Image files should be in *tif format. If figures have been created with Excel, please submit the original Excel file and the chart that has been generated.

\section{Author's alterations}

Alterations to page proofs which are not required to correct material will be charged to the author.

\section{Copyright}

Authors of articles or reviews accepted for publication will be asked to assign copyright, on certain conditions, to the Canadian Association on Gerontology.

\section{Sexist language}

Authors should avoid using sexist language in their manuscripts. For further clarification, please refer to the APA guidelines.
LA REVUE CANADIENNE DU VIEILLISSEMENT

Renseignement généraux et protocole de présentation

La Revue canadienne du vieillissement est une publication trimestrielle de l'Association canadienne de gérontologie, dotée d'un comité de lecture. Elle publie des articles qui portent sur le vieillissement dans les disciplines suivantes : biologie, politique et pratique sociales, pyschologie, sciences de la santé et sciences sociales. La Revue accepte les comptes rendus de recherches originales ainsi que les textes conceptuels ou théoriques qui font avancer de façon appréciable les connaissances ou la vision de la gérontologie. On demande aux auteurs de tenir compte de la multidisciplinarité du lectorat. Il peut s'avérer particulièrement approprié de relier certains aspects de l'analyse à d'autres domaines de savoir.

Dans la revue, il a aussi de la place dans les sections Critique de livres (Book Reviews), Notes de recherche (Research Notes) et Notes sur les politiques et pratiques (Policy and Practice Notes). Une note de recherche est un rapport sommaire au plan théorique ou politique. Une note sur les politiques et pratiques est un rapport sommaire au plan de l'amélioration des pratiques ou de la prestation d'un service particulier. Chaque section peut être utilisée pour présenter des études de cas importantes, des rapports psychométriques, des normes d'essai canadiennes, une évaluation d'approches méthodologiques, les résultats d'études pilotes ou de réplique, et des résumés d'études d'évaluation des programmes. Les auteurs doivent indiquer clairement si leur objectif une note de recherche ou une note de politique et pratique. Ces présentations doivent comprendre au maximum 5000 mots plus de références, des figures, et des tableaux. Les auteurs d'une note doivent indiquer, le cas échéant, qu'un rapport plus détaillé sera fourni sur demande.

\section{Presentation et acceptation des manuscrits}

La Revue canadienne du vieillissement accepte les soumissions de manuscrit par le système de ScholarOne Manuscripts à http:/ / mc.manuscriptcentral.com/cja-rcv. Pour des questions concernant les «Renseignement généraux et protocole de presentation, $\gg$ s'il vous plaît contacter le rédacteur en chef, Paul Stolee à cjarcv@uwaterloo.ca.

La revue n'accepte que des manuscrits inédits qui n'ont pas été soumis à une autre revue. Les manuscrits acceptés par la $R C V$ ne peuvent être publiés ailleurs sans autorisations (exception faites des actes de conférences).

\section{Préparation des manuscrits}

a. Preparation des manuscrits. On recommande l'utilisation de logiciels compatibles avec PC. Les versions finales doivent nous parvenir en Word, à double interligne (12 pt. font). En général, les articles devraient contenir de 3000 à 10000 mots ainsi que les sources, les chiffres et les tableaux. Les auteurs sont priés de numéroter toutes les pages consécutivement (y compris la page de titre). Les manuscrits doivent être accompagnés d'un titre résumé qui servira dans l'entête contenant un maximum de 40 lettres et espaces, et six (6) mots clés pour le classement analytique.

b. La page titre. Comme un document séparé (non inclus dans le fichier du document principal), les auteurs doivent soumettre une page de titre contenant le nom de l'auteur, dernier diplôme obtenu, nom et adresse de l'affiliation institutionnelle, adresse électronique, numéro de télécopie, numéro de téléphone.

c. Anonymat de l'auteur. Le fichier du manuscrit (document principal) doit être anonyme, c'est-à-dire sans aucun détail de l'auteur. Le titre du manuscrit, les mots clés et le résumé devraient être inclus dans le fichier du document principal.

d. Résumé. Les manuscrits doivent être accompagnés d'un résumé de 150 mots

e. Remerciements. Les remerciements doivent être inclus sur la page de titre et sera intégrés dans une note préliminaire en première page de l'article imprimé. f. Notes. Les notes doivent figurer à la fin du texte, immédiatement avant la bibliographie. Nous ne pouvons accepter les notes en base de page.

g. Références. Les références doivent être conforme au protocole de l'American Psychological Association (2009, 6e Édition). Pour obtenir de plus amples reseignements sur ce point consulter la rédaction.

h. Tableaux. Les tableaux doivent être présentés sous forme de fichiers distincts, idéalement en format tableau de Word.

i. Figures. Les illiustrations doivent être prêtes à photographier et soumises en même temps que la version finale du texte. Format max. : 43 picas / 7 po $1 / 4$ lar. sur 58 picas / 7 po $3 / 4$ haut. Les fichier électroniques contenant des images, doivent être en format TIFF.

\section{Modifications de l'auteur}

Les corrections effectuées par l'auteur à la lecture d'épreuve seront portées à son compte.

\section{Droits de l'auteur}

Les auteurs dont les articles ou les résumés sont publiés doivent céder, à certaines conditions, leurs droits d'auteur à Association canadienne de gérontologie.

\section{Formulation sexiste ou discriminatoire}

Les auteurs doivent éviter l'emploi de tournures sexistes ou discrimimatoires. Pour, plus de précisions, s'il vous plaît consulter les lignes directrices APA. 
Cambridge Core

For further information about this journal please go to the journal website at: cambridge.org/cig

\begin{tabular}{|c|c|}
\hline ISC & $\begin{array}{c}\text { MIX } \\
\text { Paper from } \\
\text { responsible sources }\end{array}$ \\
\hline & $\mathrm{FSC}^{\otimes} \mathrm{C} 012947$ \\
\hline
\end{tabular}

CAMBRIDGE UNIVERSITY PRESS 